\title{
First records of a blind centipede, Cryptops navis Chamberlin, 1930 (Chilopoda, Scolopendromorpha, Cryptopidae), from Japan
}

\author{
Taro Jonishi ${ }^{1}$, Takafumi Nakano ${ }^{2}$ \\ 1 Faculty of Agriculture, Kyoto University, Kyoto 606-8502, Japan. 2 Department of Zoology, Graduate School of Science, Kyoto University, \\ Kyoto 606-8502, Japan. \\ Corresponding author: Taro Jonishi, ykn347635@gmail.com
}

\begin{abstract}
Eight specimens of a scolopendromorph centipede collected in Tokashiki Island and Minamidaito Island (both in the Ryukyu Islands, Japan) represent the first record of Cryptops (Cryptops) navis Chamberlin, 1930 from the islands of the Far East (i.e., Japanese Archipelago, Ryukyu Islands and Taiwan). This material also provides new details of the morphological variability of $C$. (C.) navis and the first data on natural habitats of $C$. $(C$.) navis, which previously was known only from soil samples from Singapore and China.
\end{abstract}

\section{Keywords \\ Cryptops s. str., Daito Islands, doriae group, Kerama Island, Ryukyu Islands.}

\begin{abstract}
Academic editor: Stephanie F. Loria | Received 5 May 2020 | Accepted 6 July 2020 | Published 10 July 2020
Citation: Jonishi T, Nakano T (2020) First records of a blind centipede, Cryptops navis Chamberlin, 1930 (Chilopoda, Scolopendromorpha, Cryptopidae), from Japan. Check List 16 (4): 865-869. https://doi.org/10.15560/16.4.865
\end{abstract}

\section{Introduction}

The scolopendromorph genus Cryptops Leach, 1814 comprises more than 170 species described worldwide (Bonato et al. 2016) that have been classified into four or five subgenera (Vahtera et al. 2013; Lewis 2016). Lewis (2011) has divided Cryptops sensu stricto into two groups based on the presence of an anterior transverse suture on tergite 1 . Subsequently, this author also divided the group lacking this suture into two species groups, doriae and hortensis, based on the presence of one or more saw teeth on the ultimate leg femur.

To date, three species of Cryptops sensu stricto have been recorded from the Japanese Archipelago, the Ryukyu Islands, and Taiwan (islands of the Far East): C. (C.) nigropictus Takakuwa, 1936, C. (C.) japonicus Takakuwa, 1934 and C. (C.) striatus Takakuwa, 1936 (Chao and Chang 2003, 2008; Shinohara et al. 2015).
Cryptops (C.) nigropictus belongs to the hortensis group (Lewis 2011), and C. (C.) japonicus to the doriae group (Lewis 2013) (both having tergite 1 without sutures), while $C$. (C.) striatus belongs to the group that possesses an anterior transverse suture on tergite 1 . In the Ryukyu Islands, all three species were recorded from a montane region of the Okinawa Island (Ômine and Itô 1998).

We recently collected individuals of Cryptops sensu stricto from two islands in the Ryukyu Islands, Japan. Morphological examination indicated that these newly collected specimens certainly belong to the doriae group, and they were identified as C. (C.) navis Chamberlin, 1930 , which has never been recorded from the islands of the Far East. Data on the natural habitats of $C$. (C.) navis are also provided for the first time; previously this species was only found in two soil samples transported 
to Honolulu (Hawaii) from Singapore (the type locality) and China (without precise location) (Chamberlin 1930, 1940; Lewis 2013) (Fig. 1).

\section{Methods}

Six specimens were collected from around a paddy field in Tokashiki Island (Fig. 2A, B), in the Kerama Islands (Okinawa Prefecture), and two specimens were obtained near the seashore in Minamidaito Island (Fig. 2C), in the Daito Islands (Okinawa Prefecture), Japan. The material was fixed and preserved in absolute ethanol. All eight specimens were examined using a Leica M125C stereoscopic microscope (Leica Microsystems, Wetzlar, Germany). Images were captured with the aid of a Leica MC170 HD digital camera mounted on the Leica M125C, and prepared using Leica Application Suite v. 4.12 software. Examined specimens are deposited in the Zoological Collection of Kyoto University (KUZ). Terminology of morphological characters follows Lewis et al. (2005) and Bonato et al. (2010).

\section{Results}

Order Scolopendromorpha

Family Cryptopidae Kohlrausch, 1881

Genus Cryptops Leach, 1814

\section{Cryptops (Cryptops) navis Chamberlin, 1930}

Figures 1-4

[New Japanese name: Futamata-menashimukade, フタマ タメナシムカデ]

Cryptops navis Chamberlin 1930: 65.

Cryptops sinesicus Chamberlin 1940: 49.

Cryptops (Cryptops) navis—Lewis 2013: 19, figs 50-54.

Cryptops (Cryptops) sinesicus - Lewis 2013: 25-26, figs 67-69.

New records. JAPAN - 1 specimen; Ryukyu Islands, Kerama Islands, Tokashiki Island; $26^{\circ} 11.77^{\prime} \mathrm{N}, 127^{\circ}$ 21.66'E; alt. 13 m; 13 Mar. 2019; Taro Jonishi leg.; under straws near a paddy field; KUZ Z2974. - 5 specimens; same collection data as for KUZ Z2974; 14 Mar. 2019; KUZ Z2975 to Z2979. • 2 specimens; Ryukyu Islands, Daito Islands, Minamidaito Island, Shioya Beach; $25^{\circ} 49.64^{\prime} \mathrm{N}, 131^{\circ} 12.97^{\prime} \mathrm{E}$; alt. $17 \mathrm{~m}$; 29 Oct. 2019 ; Takafumi Nakano leg.; under fallen leaves along a road; KUZ Z2980 to Z2981.

Identification. Body length $12-17 \mathrm{~mm}$. Color brownish yellow (Fig. 3A). Antennae of 17 articles; basal 3-4 articles with long setae, number of long setae decreasing toward distal articles, subsequent articles pilose (Fig. 3B, E). Cephalic plate without sutures, posterior margin overlapped by tergite 1 (Fig. 3B, C). Clypeus with $2+$ $1+2$ setae and 5-6 prelabral setae (Fig. 3D). Anterior margin of forcipular coxosternite weakly bilobed, with $3+3$ submarginal setae of which lateral ones smallest (absent in smaller specimens: KUZ Z2975, Z2977) (Fig. $3 \mathrm{E})$. Calyx of poison gland ovoid, located in anterior part

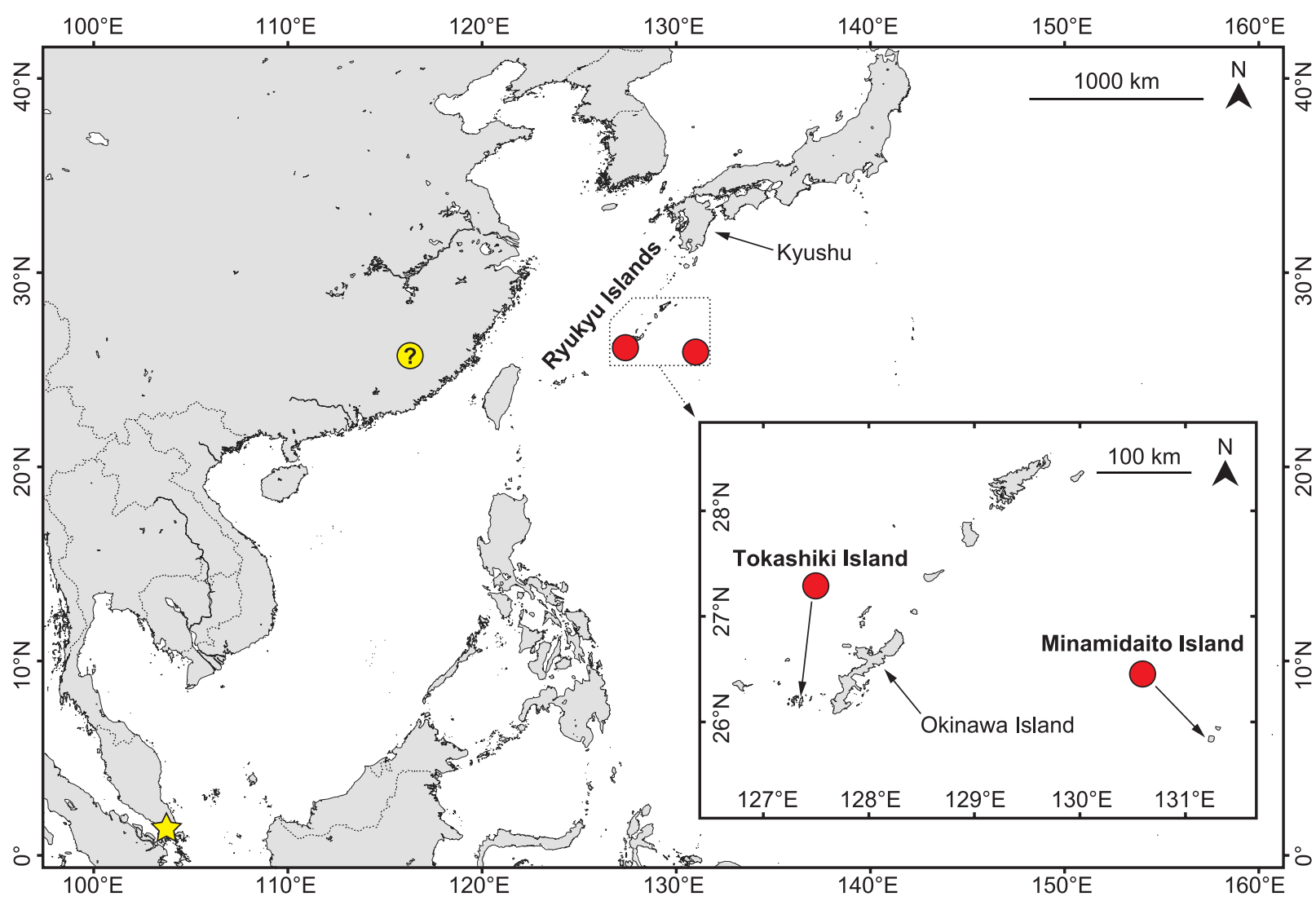

Figure 1. Map showing the collection localities of Cryptops (C.) navis Chamberlin, 1930. Red circles denote the new locations; a yellow star and circle represent the type locality and previously known locality, respectively. Shoreline data based on Wessel and Smith (1996). 

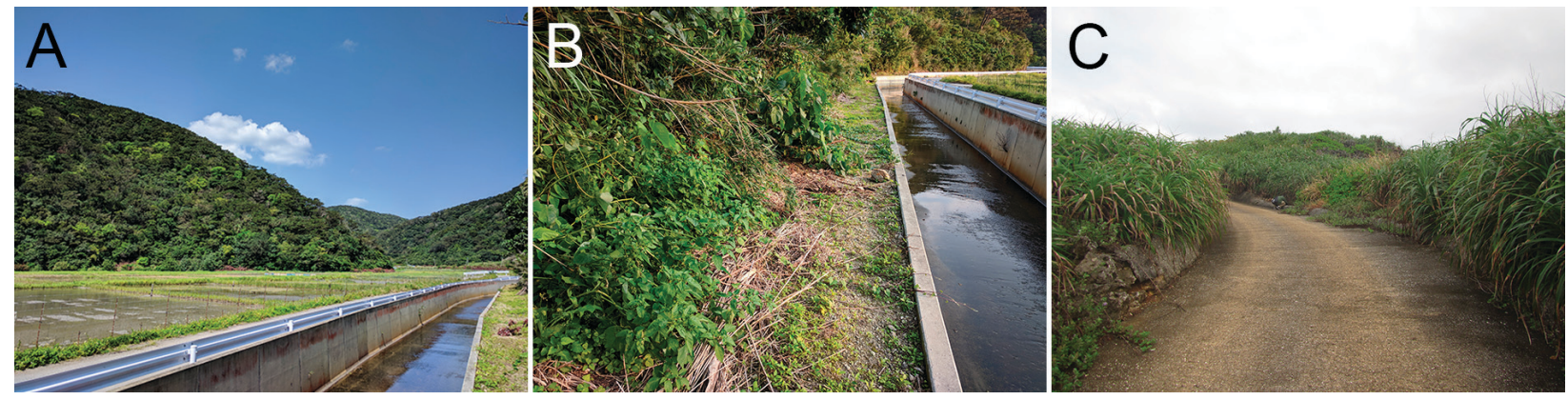

Figure 2. Habitats of Cryptops (C.) navis Chamberlin, 1930 in Tokashiki (A, B) and Minamidaito (C) islands. A. A paddy field. B. Vegetation and straw near a paddy field, where specimens were collected. C. Vegetation along a road near the seacoast.

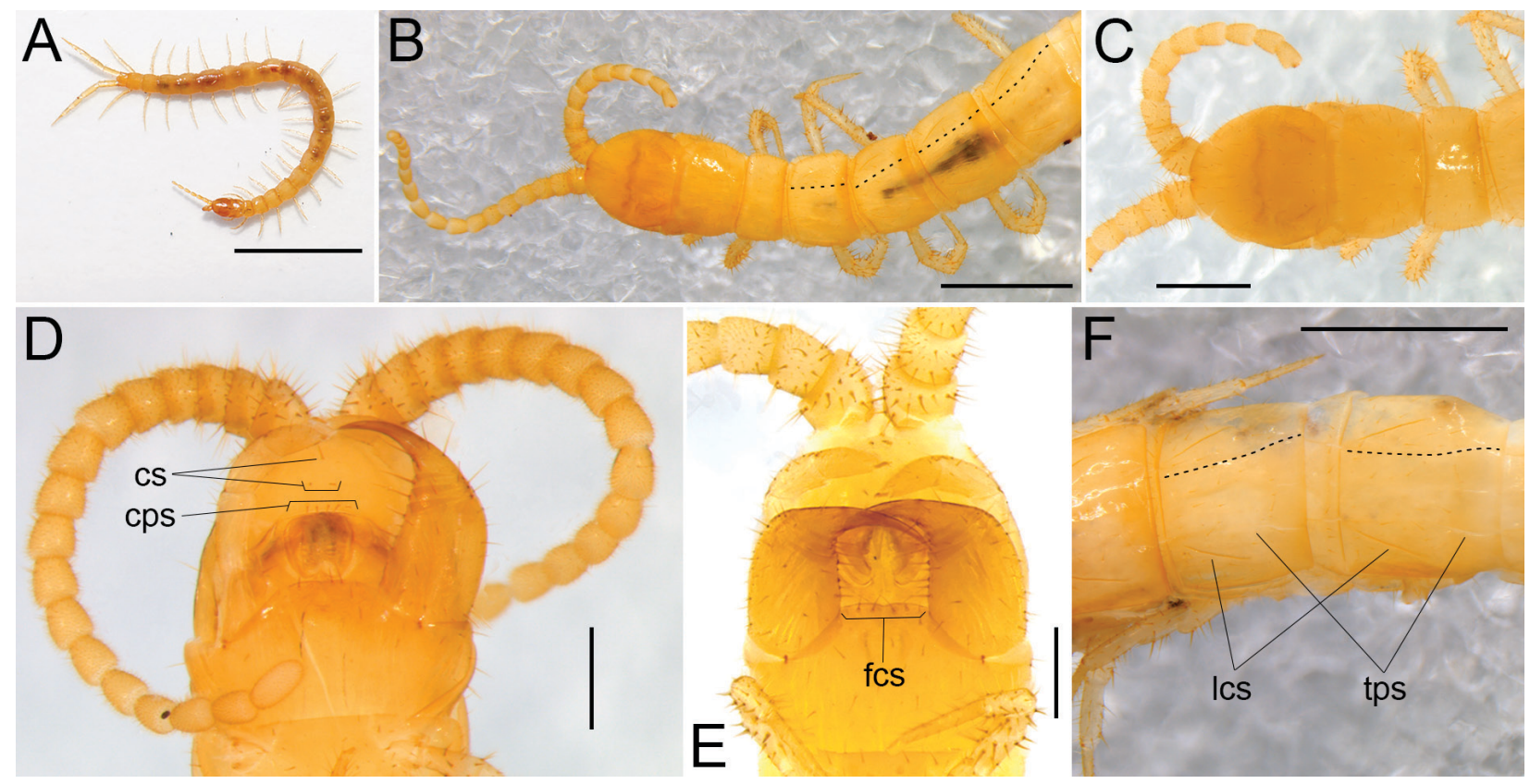

Figure 3. Cryptops (C.) navis Chamberlin, 1930, KUZ Z2974 (A-C, E, F) from Tokashiki Island, and KUZ Z2980 (D) from Minamidaito Island. A. Live specimen, dorsal view. B. Cephalic plate, tergites 1-7, dorsal view. C. Cephalic plate and tergite 1, dorsal view. D. Head (right forcipule removed), ventral view; anteriormost two clypeal setae overlapped by second maxillae. E. Head, ventral view. F. Tergites 9-10, dorsal view. Dashed lines denote right tergital paramedian sutures. Abbreviations: cps, clypeal prelabral seta; cs, clypeal seta; fcs, forcipular coxosternite submarginal seta; Ics, lateral crescentic sulcus of tergite; tps, tergital paramedian suture. Scale bars: $5 \mathrm{~mm}(\mathbf{A}) ; 1 \mathrm{~mm}(\mathbf{B}, \mathbf{F})$; $0.5 \mathrm{~mm}(\mathbf{C}) ; 0.25 \mathrm{~mm}(\mathbf{D}, \mathbf{E})$.

of trochanteroprefemur. Tergites 1 and 2 without sutures; paramedian sutures complete on tergites 3-20; lateral crescentic sulci present on tergites 3-20 (Fig. 3B, F). Sternites with cruciform sutures of which transverse suture curved and median longitudinal suture shorter than transverse one; sternite 21 with sides slightly converging posteriorly, corners broadly rounded (Fig. 4A). Coxopleuron with 12-23 coxal pores, dorsal area with 0-2 minute and 2-3 enlarged setae, posterior margin with a few minute and 3-5 enlarged ones, and 0-2 enlarged ones between pore field and posterior margin; pore-field covering anterior half of coxopleuron, with a few minute setae and enlarged ones (Fig. 4B). Ultimate legs with fine setae, plus numerous enlarged setae on prefemur (laterally, ventrally and medially) and femur (ventrally and medially) (Fig. 4C, D); prefemur with longitudinal glabrous area medially (sparsely setose in KUZ Z2980) (Fig. 4D, E); femur, tibia and tarsus 1, respectively, with 1, 5-7 and 2 saw teeth, distal one on tibia bifid (Fig. 4F).
Legs 1-19 with undivided tarsus, and single pretarsal accessory spine nearly half as long as pretarsus (Fig. 4G). Prefemur, femur and tibia of leg 20 with dense short setae ventrally (Fig. 4H).

\section{Discussion}

The examined specimens were identified as Cryptops (Cryptops) navis based on the following features: $2+1$ +2 clypeal setae, one saw tooth on ultimate leg femur and ultimate leg tibia with bifid distal saw tooth, and locomotory legs with a single and comparatively long (nearly half as long as corresponding pretarsus) pretarsal accessory spine (Chamberlin 1930, 1940; Lewis 2013). Although the present specimens possess forcipular coxosternite with $3+3$ submarginal setae and sternite 21 with broadly rounded corners, which are concordant with the descriptions of both Chamberlin (1930) and Lewis (2013), both the setal arrangement of forcipular 


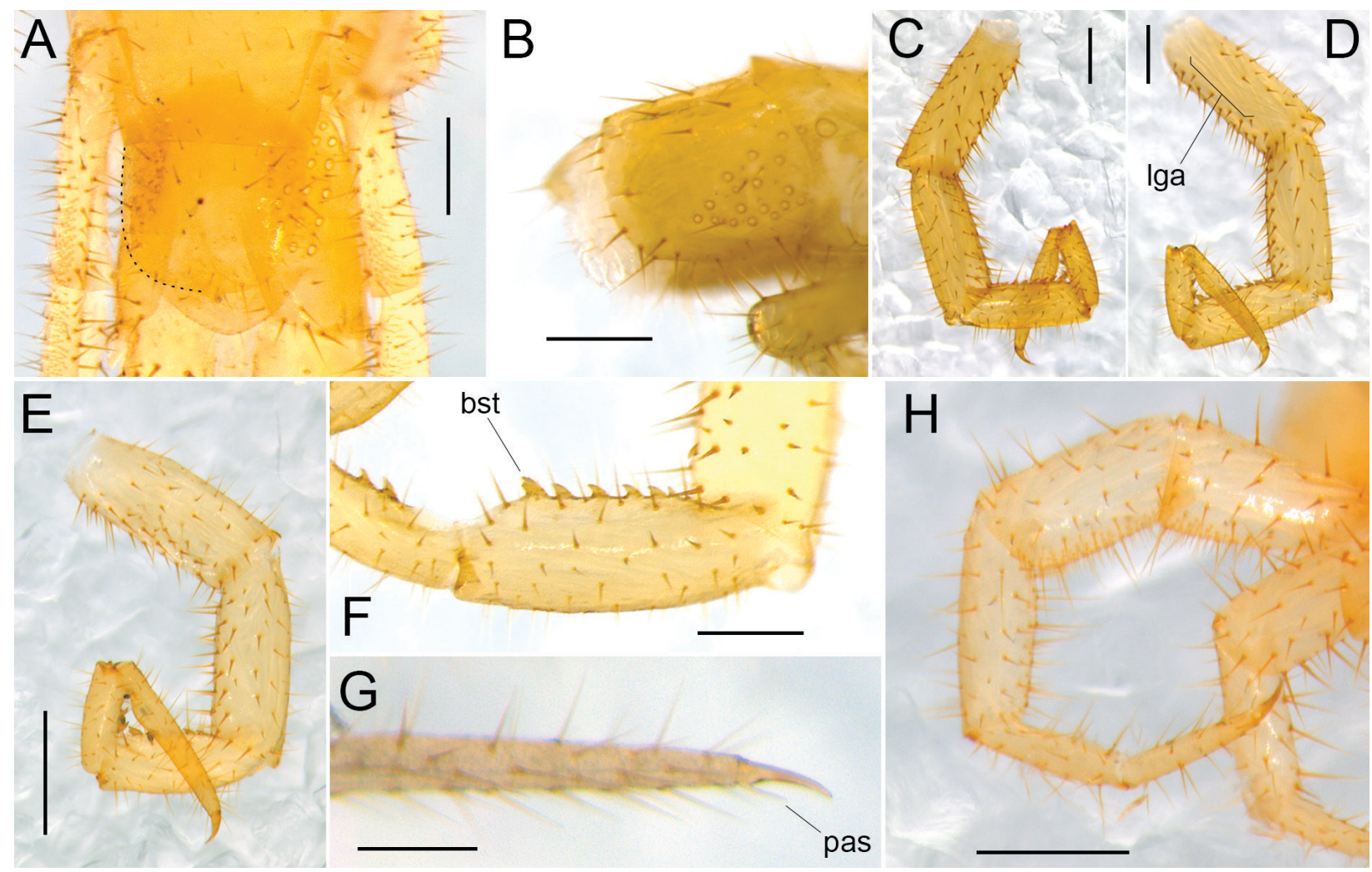

Figure 4. Cryptops (C.) navis Chamberlin, 1930, KUZ Z2974 (A, F, G) and Z2978 (B-D) from Tokashiki Island, and KUZ Z2980 (E, H) from Minamidaito Island. A. Sternite 21, ventral view; the dashed line indicates its right margin. B. Right coxopleuron (ultimate legs removed), lateral view. C. Right ultimate leg, lateral view. D. Right ultimate leg, medial view. E. Right ultimate leg, medial view. F. Saw teeth on tibia of right ultimate leg, medial view. G. Pretarsus of leg 12, medial view. H. Leg 20, lateral view. Abbreviations: bst, bifid saw tooth; Iga, longitudinal glabrous area; pas, pretarsal accessory spine. Scale bars: $0.2 \mathrm{~mm}(\mathbf{A}, \mathbf{B}, \mathbf{F}) ; 0.25 \mathrm{~mm}(\mathbf{C}-\mathbf{E}, \mathbf{H}) ; 0.1 \mathrm{~mm}(\mathbf{G})$.

coxosternite and shape of sternite 21 are variable in some Cryptops species (Lewis 2009, 2013; Schileyko and Stoev 2016).

The Ryukyu specimens differ from previous descriptions (Chamberlin 1930, 1940; Lewis 2013) in the following characteristics: 5-6 (vs 9) prelabral setae on clypeus, 12-23 (vs 32-60) coxal pores, and a longitudinal glabrous (vs setose) area on the ultimate leg prefemur. However, the number of prelabral setae was reported as a variable character in C. (C.) parisi Brolemann, 1920 (Iorio and Geoffroy 2003), and the number of coxal pores is highly variable even intraspecifically (Lewis 1999; Schileyko 2008). The specimens from Tokashiki Island also possess the longitudinal glabrous area on the ultimate leg prefemur, which has been treated as a diagnostic characteristic for some Cryptops species (Lewis 2013, 2016). Nevertheless, the ultimate leg prefemur is sparsely setose in the specimen from Minamidaito Island, and the glabrous area was not observable in the holotype (Lewis 2013). Given the fact that the discordant details listed above are known to be variable in the other Cryptops species (even varying among the Ryukyu populations), we consider the present specimens to be $C$. $(C$.) navis. The number of prelabral setae and coxal pores, as well as the presence of a longitudinal glabrous area on the ultimate leg prefemur, may represent intraspecific variations of $C$. (C.) navis.

Only two specimens of $C$. $(C$.) navis have been previously reported, and the precise distribution of this species was uncertain (Chamberlin 1930, 1940; Lewis 2013). The studied material, collected under straw close to paddy fields and under fallen leaves near the seashore in Tokashiki Island and Minamidaito Island, respectively, therefore provides the first data on the natural habitats of $C$. (C.) navis. According to Chamberlin $(1930,1940)$ and the present results, the northern border of the range of this species is Tokashiki and Minamidaito islands, and the southernmost is Singapore (the type locality) (Fig. 1). Because only the holotype of $C$. sinesicus Chamberlin, 1940 (=C. (C.) navis; see Lewis 2013) was recorded from China (see Song et al. 2010), the precise distribution of $C$. (C.) navis in China cannot be determined. However, it is possible that the type locality of $C$. sinesicus is located along the coastline of Southern China, because this species was collected from the small islands within the Ryukyu Islands, and was found in the soil from Singapore.

The present findings revealed morphological variations among the two populations in the Ryukyu Islands, and suggest that these characteristics could be intraspecific variations of $C$. (C.) navis. However, a detailed understanding of the intraspecific variations of this species remains hampered by a lack of sufficient material from other localities. With the aid of the habitat information of C. (C.) navis in the Ryukyu Islands, further faunal surveys in Southeast and East Asia are necessary to clarify the true range of this species. Then, additional 
specimens obtained in future surveys will help elucidate the precise intraspecific morphological variations of $C$. (C.) navis.

\section{Acknowledgements}

The authors are grateful to Dr Arkady A. Schileyko (Moscow Lomonosov State University), Dr Stephanie F. Loria (American Museum of Natural History), and the two anonymous reviewers for their valuable comments and suggestions on this manuscript. We thank Tomoyuki Takahashi (Kyoto University) for his help in material collection, and Michael Luetchford and Dr Harry Taylor (both Edanz Group) for editing a draft of this manuscript. This study was partially supported by the Grants-in-Aid for Scientific Research of the Japan Society for the Promotion of Science (JSPS KAKENHI Grant Number JP18K14780).

\section{Authors' Contributions}

TJ conceived the study, examined and photographed specimens, and drafted the manuscript. TN drew the map and improved the manuscript and figures. Both authors read and approved the final manuscript.

\section{References}

Bonato L, Edgecombe GD, Lewis JGE, Minelli A, Pereira LA, Shelley RM, Zapparoli M (2010) A common terminology for the external anatomy of centipedes (Chilopoda). ZooKeys 69: 17-51. https://doi.org/10.3897/zookeys.69.737

Bonato L, Chagas Jr A, Edgecombe GD, Lewis JGE, Minelli A, Pereira LA, Shelley RM, Stoev P, Zapparoli M (2016) ChiloBase 2.0-a world catalogue of centipedes (Chilopoda). https:// chilobase.biologia.unipd.it. Accessed on: 2020-4-23.

Chamberlin RV (1930) On some chilopods immigrant at Hawaii. PanPacific Entomologist 7 (2): 65-69.

Chamberlin RV (1940) Diagnoses of ten new chilopods with a new genus of Sogonidae and a key to the species of Lophobius. PanPacific Entomologist 16 (2): 49-56.

Chao J-L, Chang H-W (2003) The scolopendromorph centipedes (Chilopoda) of Taiwan. African Invertebrates 44 (1): 1-11. https:// doi.org/10520/ejc84516

Chao J-L, Chang H-W (2008) Neotype designation for two centipedes, Scolopocryptops curtus (Takakuwa, 1939) and Cryptops nigropictus Takakuwa, 1936, and a review of species of Scolopendromorpha (Chilopoda) in Taiwan. Collection and Research 21: $1-15$.

Iorio E, Geoffroy J-J (2003) Etude des Scolopendromorphes français du genre Cryptops Leach, 1814 - Première partie: Cryptops parisi Brolemann, 1920 et C. parisi var. cristata Ribaut, 1925 (Chilopoda, Scolopendromorpha, Cryptopidae). Bulletin de Phyllie 18: 28-37.

Lewis JGE (1999) On the genus Cryptops Leach in Nepal with redescriptions of Cryptops australis Newport and C. doriae Pocock (Chilopoda, Scolopendromorpha, Cryptopidae). Senckenbergiana Biologica 79 (1): 19-38.

Lewis JGE (2009) A review of some characters used in the taxonomy of Cryptops (subgenus Cryptops) (Chilopoda: Scolopendromorpha: Cryptopidae). Soil Organisms 81 (3): 505-518.

Lewis JGE (2011) A review of the species in the genus Cryptops Leach, 1815 from the Old World related to Cryptops (Cryptops) hortensis (Donovan, 1810) (Chilopoda, Scolopendromorpha). International Journal of Myriapodology 4: 11-50. https://doi. org/10.3897/ijm.4.1116

Lewis JGE (2013) A review of the species in the genus Cryptops Leach, 1815 from the Old World and the Australasian region related to Cryptops (Cryptops) doriae Pocock, 1891 (Chilopoda: Scolopendromorpha: Cryptopidae). Zootaxa 3683 (1): 1-34. https://doi.org/10.11646/zootaxa.3683.1.1

Lewis JGE (2016) On the Cryptops subgenus Trichocryptops Verhoeff, 1937, with a discussion of the problems of differentiating Cryptops species (Chilopoda: Scolopendromorpha: Cryptopidae). Zootaxa 4139 (4): 575-584. https://doi.org/10.11646/ zootaxa.4139.4.9

Lewis JGE, Edgecombe GD, Shelley RM (2005) A proposed standardised terminology for the external taxonomic characters of the Scolopendromorpha (Chilopoda). Fragmenta Faunistica 48 (1): $1-8$.

Ômine T, Itô Y (1998) Abundance and diversity of soil macrofauna of forests in Yanbaru, Northern montane part of Okinawa Island, with special reference to removal of undergrowth. Okinawa Daigaku Kiyo 15: 131-159.

Schileyko AA (2008) The scolopendromorph centipedes (Chilopoda) of Vietnam, with contributions to the faunas of Cambodia and Laos. Part 3. Arthropoda Selecta 16 (2): 71-95.

Schileyko AA, Stoev PE (2016) Scolopendromorpha of New Guinea and adjacent islands (Myriapoda, Chilopoda). Zootaxa 4147 (3): 247-280. https://doi.org/10.11646/zootaxa.4147.3.3

Shinohara K, Takano M, Ishii K (2015) Arthropoda. Myriapoda. Chilopoda. In: Aoki J-i (Ed) Pictorial Keys to Soil Animals of Japan. The Second Edition. Tokai University Press, Hadano, 873-910.

Song Z-S, Zhu M-S, Liang A-P (2010) The genus Cryptops Leach (Scolopendromorpha, Cryptopidae, Cryptopinae) in China, with descriptions of a new species and a new record species. Acta Zootaxonomica Sinica 35 (2): 376-380.

Vahtera V, Edgecombe GD, Giribet G (2013) Phylogenetics of scolopendromorph centipedes: can denser taxon sampling improve an artificial classification? Invertebrate Systematics 27 (5): 578-602. https://doi.org/10.1071/IS13035

Wessel P, Smith WHF (1996) A global, self-consistent, hierarchical, high-resolution shoreline database. Journal of Geophysical Research: Solid Earth 101 (B4): 8741-8743. https://doi. org/10.1029/96jb00104 